\title{
ASUPAN ENERGI DAN PENGGUNAAN ENERGI (ENERGY EXPENDITURE) SELAMA KEHAMILAN: STUDI LONGITUDINAL
}

\author{
Yuniar Rosmalina, Amalia Safitri, Fitrah Ernawati \\ Pusat Teknologi Terapan Kesehatan dan Epidemiologi Klinik, Bogor \\ yrosmalina@gmail.com
}

\begin{abstract}
ABSTRAK
Selama kehamilan, asupan gizi seharusnya datang dari makanan yang baik dalam jumlah dan kualitas karena sangat penting untuk perkembangan kehamilan yang sehat. Selain itu keadaan kesehatan ibu selama kehamilan sangat mempengaruhi perkembangan janin, Tujuan tulisan ini adalah membandingkan energi yang masuk dengan energi yang dikeluarkan dalam melakukan kegiatan sehari. Penelitian ini adalah longitudinal yang mengikuti respondents dalam kaitannya dengan asupan energi dan pengeluaran energi dari usia kehamilan 3 bulan sampai usia 8 bulan dengan melakukan. Jumlah responden pada awal studi di trimester pertama (awal rekruitment) adalah 334 ibu dan pada akhir studi adalah 262 ibu. Data yang dikumpulkan meliputi karakteristik, berat badan,aktifitas fisik dan konsumsi makanan (melalui recall 1 x 24 jam). Berat badan, aktifitas fisik dan konsumsi makanan dikumpulkan setiap 2 minggu. Hasil menunjukkan bahwa asupan energi dan energi yang dikeluarkan relatif sama. Juga didapat rerata berat badan ibu pada kehamilan yang ke 3 bulan adalah 48,7 $\mathrm{kg}$ dan kemudian bertambah sesuai dengan perkembangan kehamilan. Rerata kenaikan berat badan dari usia 3 bulan ke 8 bulan kehamilan asupan energi, adalah $7,5 \mathrm{~kg}$. Asupan energite rendah saat kehamilan 3 bulan yaitu $2000 \mathrm{Kal}$ sehari kemudian meningkat pada kehamilan yang ke 7 bulan dan menurun kembali pada umur kehamilan ke 8 bulan.
\end{abstract}

Kata kunci: asupan energi, pengeluaran energi, ibu hamil

\section{ABSTRACT}

\section{ENERY INTAKE AND ENERGY EXPENDITURE DURING PREGNANCY: A LONGITUDINAL STUDY}

During pregnancy, nutrient intakes should come from both good quality and quantity foods because they are very important for developing healthy pregnancy. In addition to nutrient intake, health status during pregnancy greatly affects fetal development. This paper aims to study a comparison of the energy intake of pregnant women with energy expenditure in performing daily activities. This is a longitudinal study which followed respondents in relation to energy intake and energy expenditure from the age of 3 months until the age of 8 months of pregnancy. The number of respondents at the beginning of the first trimester of pregnancy/initial recruitment) was 334 mothers and the end of the study became262 mothers. Data collected included respondent characteristics (age, education, occupation), body weight, physical activity, nutrient intake using a 24-hour recall method. Body weight, physical activity and food consumption were collected every 2 weeks. The results indicated that energy intake and energy expenditure were at the average per month. Also showed an average maternal weight at the age of 3 months (initial recruitment) was $48.7 \mathrm{~kg}$ and the weight increased with increasing gestational age. The average increase in weight in the initial recruitment at the age of 8 months of pregnancy was on $7.5 \mathrm{~kg}$. The lowest energy intake at 3 month pregnancy was $982 \mathrm{kcal}$ per day, then increasing energy intake with increasing gestational age, but the average energy intake was only 50 percent compared to energy expenditure for their daily activities. The average energy expenditure was low at the age of 3 months of pregnancy, about $2000 \mathrm{kcal}$ and increased until the age of 7 months of pregnancy then declined at the age of 8 months of pregnancy.

Keywords: energy intake, energy expenditure, pregnant women

\section{PENDAHULUAN}

eribu hari periode emas kehidupan dimulai sejak bayi dalam kandungan atau dimulai pada saat ibu mengandung janinnya dari usia konsepsi hingga anak berusia
24 bulan. Oleh karenanya asupan zat gizi yang baik dari segi kualitas dan kuantitasnya sangatlah penting. Selain asupan zat gizi, status kesehatan selama masa kehamilan sangat berpengaruh terhadap perkembangan janin. Transfer zat gizi melalui plasenta dalam masa 
embrional sepenuhnya tergantung dari asupan zat gizi ibu. Padahal banyak ibu hamil yang mengalami defisiensi zat gizi yang mengakibatkan dampak buruk terhadap perkembangan janin yang nantinya berpengaruh terhadap pertumbuhan dan perkembangan anak.

Anemia merupakan masalah yang sering muncul pada masa kehamilan. Anemia pada masa kehamilan dapat disebabkan karena asupan zat besi yang tidak cukup dan penyerapan zat besi yang tidak adekuat. Selain itu pada masa kehamilan terjadi peningkatan kebutuhan zat besi untuk pembentukan hemoglobin. ${ }^{1}$

Kebutuhan energi untuk kehamilan yang normal perlu tambahan kira-kira 80.000 kilokalori selama masa kurang lebih 280 hari. Hal ini berarti perlu tambahan energi ekstra sebanyak 300-350 kilokalori setiap hari selama hamil. Kebutuhan energi mulai meningkat pada trimester pertama, kemudian lebih meningkat lagi sepanjang trimester kedua ,ketiga dan sampai akhir kehamilan. Energi tambahan selama trimester kedua diperlukan untuk pemekaran jaringan ibu seperti penambahan volume darah, pertumbuhan uterus, dan payudara, serta penumpukan lemak (energy deposit). Selama trimester ketiga energi tambahan digunakan untuk pertumbuhan dan perkembangan janin dan plasenta. ${ }^{2,3}$ Kebutuhan gizi ibu hamil meningkat 15 persen dibandingkan dengan kebutuhan wanita normal. Peningkatan zat gizi ini dibutuhkan untuk pertumbuhan janin dan sisanya (60 persen) digunakan untuk pertumbuhan ibunya. Secara normal kenaikan berat badan ibu hamil berkisar antara $11-13 \mathrm{~kg} .{ }^{4}$ Kekurangan asupan zat gizi terutama energi bisa terlihat dari rendahnya kenaikan berat badan dibawah normal yang akan berdampak pada bayi berupa berat badan lahir rendah (BBLR) atau panjang badan lahir pendek (stunting). Selain itu bisa terjadi komplikasi pada saat ibu melahirkan yang bisa membahayakan ibu.

Aktifitas fisik selama kehamilan juga sangat penting diperhatikan, karena selama kehamilan kebutuhan zat gizi lebih besar dari sebelumnya. Dimana zat gizi tersebut didapatkan dari asupan makanan. Semakin berat aktifitas fisik yang dilakukan maka semakin banyak pula energi yang diperlukan oleh tubuh agar tubuh tidak kekurangan energi yang dapat mengakibatkan kurangnya zat gizi pada janin, kecacatan bahkan abortus.

Makalah ini akan menyajikan hasil penelitian longitudinal dengan melihat penggunaan energi dan dibandingkan dengan asupan energi ibu selama masa kehamilan (dari 3 bulan sampai dengan 8 bulan kehamilan).

\section{METODE PENELITIAN}

\section{Desain, waktu dan tempat penelitian}

Penelitian ini merupakan penelitian longitudinal (jangka panjang) dengan mengikuti 344 ibu hamil mulai usia kehamilan 12- 18 minggu yang dilakukan di 10 puskesmas yang ada Kabupaten Bogor, yaitu Puskesmas Sukaraja, Cibinong, Pabuaran Indah, Cigudeg, Cibungbulang, Situ Udik, Bojong Gede, Bunar, Cadas Ngampar dan Kemuning. Penelitian dimulai pada Bulan Maret sampai dengan Desember 2011.

\section{Cara Pengumpulan Data}

Sampel yang diambil adalah ibu hamil yang usia kehamilannya 12-18 minggu. Rekrutmen ibu hamil dilakukan oleh bidan yang ada di 10 wilayah puskesmas tersebut. Pada waktu yang ditentukan ibu hamil dikumpulkan di puskesmas terdekat untuk dilakukan pengukuran antropometri, wawancara dan pemeriksaan hamil oleh bidan.

Data yang dikumpulkan meliputi data karaktersistik ibu hamil ,data berat badan, data konsumsi makanan dan data aktifitas fisik ibu hamil. Pengumpulan data dilakukan oleh peneliti, tenaga litkayasa (tenaga fungsional teknis non peneliti) dan petugas puskesmas yang sudah terlatih.

Data karakterisitik ibu hamil meliputi usia ibu, umur kehamilan, umur pertama melahirkan, paritas, dan tingkat pendidikan. Pengukuran antropometri pada ibu hamil meliputi tinggi badan dan berat badan yang dilakukan tiap 2 minggu sekali sampai usia kehamilan 8 bulan. Data konsumsi dan aktifitas fisik didapatkan dengan melakukan wawancara dengan recall 24 jam (2 hari sebelumnya) yang dilakukan setiap 2 minggu, hingga usia kehamilan 8 bulan. Sama halnya dengan data konsumsi, data aktifitas fisik juga dilakukan dengan wawancara oleh peneliti atau tenaga litkayasa dengan menggunakan formulir yang sudah disiapkan. Berat badan ditimbang menggunakan 
timbangan Seca dan tinggi badan dengan alat Microtoise.

\section{Analisis Data}

Penggunaan energi dihitung dengan menggunakan metode factorial yang didasarkann pada aktifitas/kegiatan sehari mulai dari bangun tidur hingga tidur malam.Total energi expenditure (penggunaan energi) merupakan penjumlahan dari hasil perkalian lamanya tiap kegiatan dilakukan (dalam menit) dengan energi yang dibutuhkan dalam setiap kegiatan tersebut (FAO/WHO/UNU,2001)..$^{5}$ Data berat badan , asupan energi dan penggunaan energi disajikan tiap bulan dengan menghitung rata-rata dari 2 kali pengukuran/wawancara.

Data berat badan, penggunaan energi dan asupan energi disajikan secara deskriftif dengan menyajikan rerata asupan energi dan penggunaan energinya.

\section{HASIL}

\section{Karakteristik responden}

Berdasarkan data karakteristik ibu hamil yang dikumpulkan melalui wawancara pada 334 responden didapatkan bahwa, sebagian besar ibu hamil berusia lebih dari 20 tahun $(87,4 \%)$, dan sebanyak $12,6 \%$ berusia kurang dari 20 tahun. Tetapi bila dilihat umur pertama kali menikah sebanyak 50,3 persen berusia kurang dari 20 tahun.

Berdasarkan tingkat pendidikan ibu, kebanyakan masih berpendidikan rendah. Sebanyak 40,3 persen lulus Sekolah Dasar (SD), sebanyak 24,8 persen tamat Sekolah Lanjutan Tingkat Pertama (SMP) dan 14,3 persen tidak tamat SD.

Berdasarkan pekerjaan, kebanyakan dari sampel adalah ibu rumah tangga (89,5\%). Meskipun terlihat pekerjaan rumah tangga tidak terlalu berat tetapi pada kenyataannya banyak ibu yang mengeluh dengan aktifitas tersebut. Pekerjaan rumah tangga sering kali menyita waktu dan dilakukan terus menerus sehingga tanpa terasa cukup menguras energi dan menimbulkan stress.

\section{Hasil pengukuran antropometri}

Data yang dianalisis hanya data berat badan sejak awal rekruitmen (3 bulan) hingga menjelang bayi dilahirkan (8 bulan) seperti terlihat pada Gambar 1.

Tabel 1

Karakteristik Responden

\begin{tabular}{lcc}
\hline Karateristik & $\mathrm{N}(334)$ & $\%$ \\
\hline Umur ibu : & & \\
$\geq 20$ th & 292 & 87,4 \\
$\leq 20$ th & 42 & 12,6 \\
Paritas : & & \\
$1-2$ & 276 & 82,6 \\
$\quad>2$ & 58 & 17,4 \\
Umur pertama menikah : & & \\
$\quad \geq 20$ th & 166 & 49,7 \\
$\quad \leq 20$ th & 168 & 50,3 \\
Tingkat pendidikan : & & \\
Tidak tamat SD & 48 & 14,3 \\
$\quad$ Tamat SD & 135 & 40,3 \\
Tamat SLTP & 83 & 24,8 \\
$\quad$ Tamat SLTA & 54 & 16,1 \\
Perguruan Tinggi & 15 & 4,5 \\
Pekerjaan : & & \\
lbu rumah tangga & 299 & 68,6 \\
PNS & 2 & 0.6 \\
Pegawai Negeri & 6 & 1,8 \\
Pedagang/wiraswasta & 20 & 6,0 \\
Buruh & 7 & 2,1 \\
\hline
\end{tabular}


Gambar 1 memperlihatkan semakin bertambah usia kehamilan juga terjadi penambahan berat badan. Bila diasumsikan berat badan sebelum hamil sekitar rata-rata $48,7 \mathrm{~kg}$ pada awal rekrutmen (3 bulan kehamilan) dan $56,2 \mathrm{~kg}$ pada umur 8 bulan, maka terlihat rerata penambahan berat badan selama hamil tersebut sekitar $7,5 \mathrm{~kg}$.
Penggunaan energi (energy expenditure)
selama masa kehamilan

Berdasarkan hasil penelitian ini didapatkan rata-rata energi yang paling banyak digunakan (energy expenditure) adalah pada saat kehamilan ibu berusia 7 bulan dan 8 bulan (Gambar 2). Pada usia kehamilan 7 bulan ratarata energi yang digunakan adalah sebesar 2140 kkal.

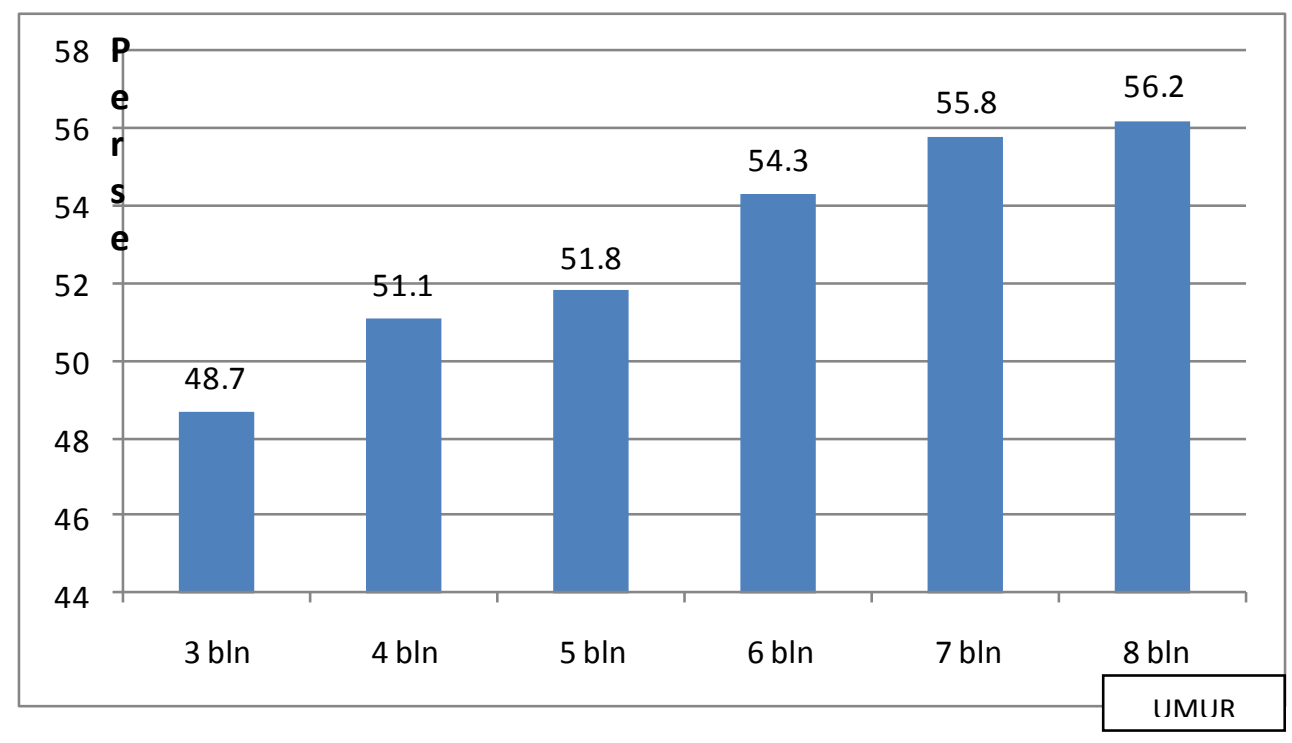

Gambar 1

Rata-Rata Berat Badan Ibu Hamil menurut Umur Kehamilan

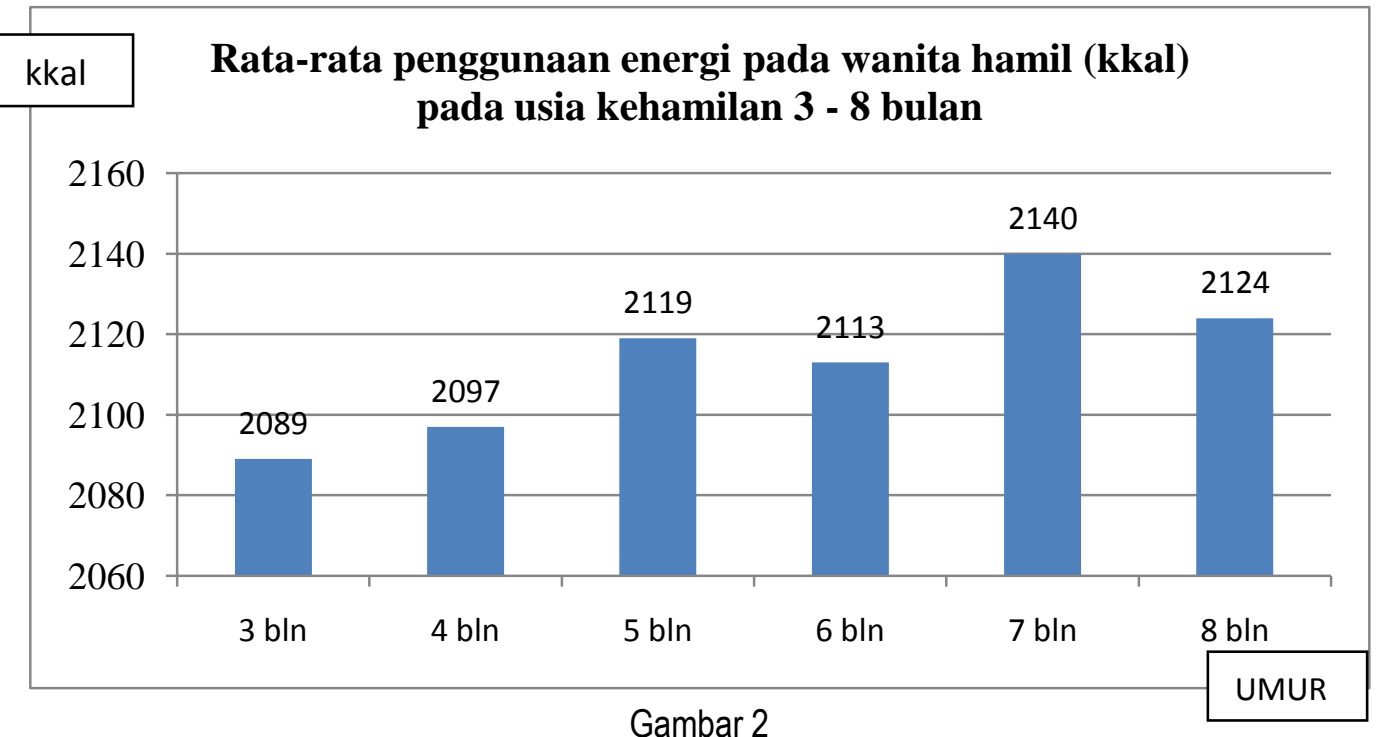

Rata-Rata Penggunaan Energi (Energy Expenditure) menurut Umur Kehamilan 


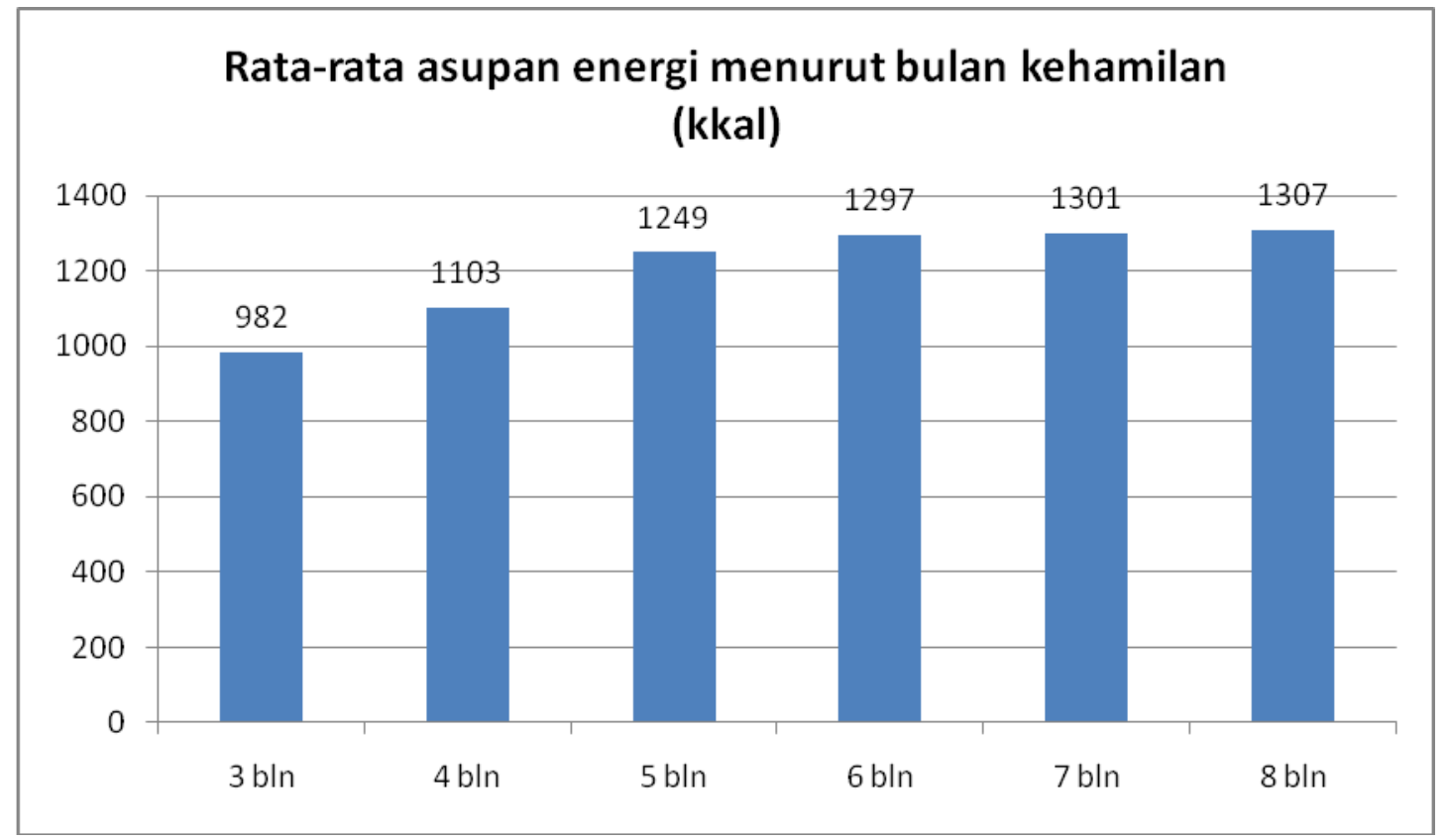

Gambar 3

Rata-Rata Asupan Energi menurut Umur Kehamilan

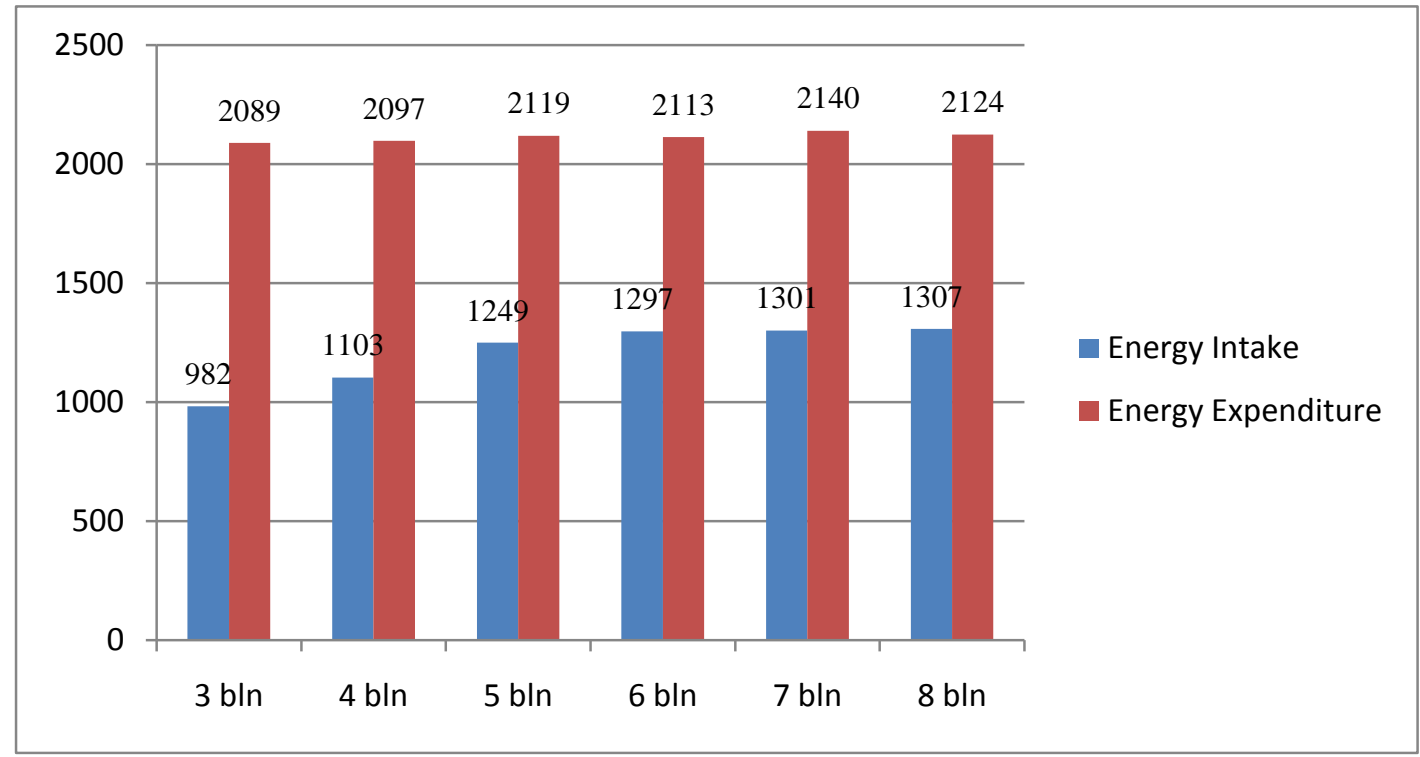

Gambar 4

Perbandingan Penggunaan Energi (Energy Expenditure) dengan Asupan Energi menurut Usia Kehamilan

Asupan energi selama masa kehamilan

Gambar 3 memperlihatkan rata-rata asupan energi selama kehamilan mulai dari kehamilan 3 bulan hingga 8 bulan kehamilan. Gambar 3 menunjukkan semakin meningkat usia kehamilan, asupan energi juga meningkat.
Namun rata-rata asupan energi pada ibu hamil paling tinggi hanya 1300 kkal. Pada masa kehamilan kebutuhan energi lebih banyak dari biasanya. Hal ini disebabkan asupan energi yang didapat tidak hanya untuk ibu tetapi juga janinnya. 


\section{Perbandingan penggunaan energi (energy expenditure) dengan asupan energy}

Gambar 4 menunjukkan rata-rata asupan energi ibu hamil pada masa kehamilan mulai dari kehamilan 3 bulan hingga 8 bulan lebih rendah dibandingkan dengan penggunaan energinya. Asupan energi hanya sekitar 50 - 70 persen dibandingkan dengan penggunaan energinya.

\section{BAHASAN}

Penelitian ini ditujukan untuk mempelajari pertambahan berat badan, asupan energi dan penggunaan energi mulai usia kehamilan 3 bulan hingga 8 bulan.

Responden ibu hamil dalam penelitian ini sekitar 80 persen mempunyai paritas 1-2 kali. Hal ini tidak sejalan dengan ketentuan pemerintah bahwa usia tepat untuk menikah bagi wanita adalah lebih dari 20 tahun, ini terkait dengan kesiapan organ reproduksi wanita untuk berproduksi (hamil). Selain itu menikah diusia muda juga rentan terjadinya kegagalan dalam kehamilan (keguguran, anak lahir cacat dII) dan gangguan organ reproduksi (kanker, penyakit menular seksual dII) akibat kurangnya pengetahuan dalam menjaga kesehatan organ reproduksinya.

Berat badan ibu hamil pada penelitian ini pada awal penelitian (sekitar 3 bulan kehamilan) rata-rata 48,7 kg. Dari Gambar 1 terlihat kenaikan berat badan rata-rata dari awal rekrutmen hingga usia kehamilan 8 bulan terlihat hanya $7,5 \mathrm{~kg}$. Kenaikan berat badan yang normal adalah sekitar $10-12 \mathrm{~kg}$ yang bisa melahirkan bayi dengan berat badan normal di atas 2500 gram. Melahirkan bayi dengan berat badan lahir rendah merupakan resiko bagi ibu dengan berat badan selama kehamilan rendah dibawah $10 \mathrm{~kg}$. Menurut Bergmann et al. peningkatan berat badan selama kehamilan berhubungan dengan Indeks Massa Tubuh (IMT) dan asupan energinya. ${ }^{6}$ Namun dalam penelitian ini tidak ditampilkan data IMTnya.

Kenaikan berat badan selama masa kehamilan yang hanya $7,5 \mathrm{~kg}$ ternyata didukung juga dari hasil analisis konsumsi energi, ternyata rata-rata hanya sekitar $50-70$ persen dari penggunaan energinya. Seharusnya asupan energi harus seimbang dengan energi yang dikeluarkan untuk melakukan aktifitas seharinya. Asupan energi paling rendah terlihat pada usia kehamilan trimester pertama, dan masa ini memang merupakan masa perubahan hormonal yang biasanya menyebabkan rasa mual-mual sehingga ibu hamil pada masa ini terganggu konsumsi makanannya. Namun selama status gizi dan status kesehatan pra kehamilan bagus, tidak ada pengaruh terhadap perkembangan janinnya, namun memasuki trimester kedua merupakan pertumbuhan janin yang cepat dan perlu diimbangi oleh asupan yang cukup. Hasil penelitian Studi diet total tahun 2014 menunjukkan sebanyak 50 persen ibu hamil baik di perkotaan maupun perdesaan asupan energinya dibawah 70 persen kecukupan energinya atau sekitar 1500 kkal. $^{7}$ Kebutuhan energi pada ibu selama masa hamil diperlukan tambahan sebesar 335MJ (80kkal) atau sekitar 1,2MJ (285kkal per hari) atau sekitar sekurang-kurangnya 0,84MJ (200kkal per hari) $)^{3}$. Tambahan energi ini diperlukan untuk mendukung kenaikan berat badan selama kehamilan dan adanya peningkatan energi basal. Namun demikian menurut Butte et al perlu juga diperhatikan IMT pada awal kehamilan dan pada ibu hamil dengan IMT normal tambahan energi bisa diabaikan, sedangkan trimester 2 perlu tambahan sebanyak 350 kilokalori per hari dan 500 kilokalori pada trimester $3 .^{8} \mathrm{Di}$ Indonesia angka kecukupan energi wanita usia 19-29 tahun sebesar $1900 \mathrm{kkal}$ dan untuk ibu hamil trimester 2 dan 3 ditambah sebesar masing-masing 300 kkal. ${ }^{9}$

Tingkat pendidikan yang rendah seringkali berhubungan dengan tingkat pengetahuan ibu mengenai kesehatan seperti perawatan sebelum melahirkan (ante natal care), proses persalinan dan perawatan kesehatan ibu dan anak pasca melahirkan. Memberikan makanan dan perawatan anak yang benar oleh ibu pada anaknya akan mempengaruhi pertumbuhan dan perkembangan anak. ${ }^{4}$

Selain asupan zat gizi ternyata tingkat stres dalam melakukan pekerjaan seorang perempuan hamil sangat mempengaruhi berat bayi yang akan dilahirkan. Dan itu, menurut sebuah penelitian sama buruknya dengan perempuan perokok saat hamil. Hasil data timbangan bayi yang dilahirkannya, berbanding lurus dengan tingkat stres karena jam kerja. Bayi dari wanita hamil yang kerja penuh stress 32 jam per minggu rata-rata 159 gram lebih 
ringan daripada bayi dari ibu yang tidak mengalami stress pada masa kehamilan. Akibat serupa ini sama dengan wanita hamil yang merokok 6 batang per hari. ${ }^{10}$

Penggunaan energi ibu hamil pada penelitian ini sekitar 2000 kkal sampai 2100 kkal sehari. Bila dibandingkan asupan energinya, penggunaan energinya lebih tinggi. Angka kecukupan energi ditentukan berdasarkan energi yang digunakan pada saat melakukan aktifitas fisik sehari-harinya serta kenaikan energi basal selama kehamilan. Ibu dengan usia subur di daerah pedesaan aktifitas fisiknya lebih tinggi dibandingkan ibu di daerah perkotaan. Bahkan pada saat hamil aktifitasnya tetap seperti biasa pada saat tidak hamil. Dengan asupan energi yang hanya 50 persen dari penggunaannya, maka dalam jangka panjang akan mengalami kekurangan energi kronis (KEK). Kekurangan energi pada awal kehamilan (status gizi kurang) lebih berisiko melahirkan bayi dengan berat badan lahir rendah (BBLR). ${ }^{11}$ Oleh karenanya perlu dilakukan pemberian suplementasi zat gizi terutama makanan sumber energi pada saat kehamilan.

\section{SIMPULAN DAN SARAN}

\section{Simpulan}

Asupan energi ibu hamil meningkat dengan meningkatnya usia kehamilan dengan penambahan rata-rata $7,5 \mathrm{~kg}$ dari usia kehamilan 3 bulan hingga 8 bulan

Asupan energi ibu hamil rata-rata lebih rendah dibandingkan dengan energi yang digunakan untuk melakukan aktifitasnya.

\section{Saran}

Upaya peningkatan asupan zat gizi terutama energi perlu dilakukan selain suplementasi besi yang sudah berjalan mengingat banyaknya ibu hamil mengalami defisit energi sementara penggunaan energinya cukup tinggi.

\section{UCAPAN TERIMA KASIH}

Ucapan terima kasih kami sampaikan kepada para Kepala Puskesmas Sukaraja, Cibinong, Pabuaran Indah, Cigudeg, Cibungbulang, Situ Udik, Bojong Gede, Bunar,
Cadas Ngampar dan Kemuning, beserta bidan di masing-masing puskesmas yang sangat membantu dalam pemeriksaan kehamilan. Terima kasih juga kami sampaikan kepada seluruh responden yang turut serta dalam penelitian, kepada teman-teman peneliti dan litkayasa sehingga penelitian berjalan dengan baik.

\section{RUJUKAN}

1. Arisman. Pencegahan dan Pengawasan Anemia Defisiensi Besi. Geneve: World HealthOrganization, 1995

2. Zulhaida L. Status Gizi Ibu Hamil Serta Pengaruhnya Terhadap Bayi Yang

3. dilahirkan. Thesis. Bogor: Program Pasca Sarjana IPB, 2003.

4. Saifuddin. Buku Acuan Nasional Pelayanan Kesehatan Maternal dan Neonatal. Jakart:. YBP-SP, 2001

5. Diana F.M. Hubungan pola asuh dengan status gizi anak batita di Kecamatan Kuranji Kelurahan Pasar Ambacang Kota Padang. Jurnal kesehatan Masyarakat 2006; 3(2): 14-22

6. FAO/WHO/UNU. Expert Consultation on Energy and Protein Requirements.1985. WHO Technical Report Series No. 724.

7. Bergmann EW, Flagg $\mathrm{HL}$, MiracleMcMahill, $\mathrm{H}$ Boeing. Energy intake and net weight gain in pregnant women according to body mass index (BMI) status. International Journal of Obesity 1997; 21: 1010-1017

8. Kementrian Kesehatan. Studi Diet Total: Survei Konsumsi Makanan Individu Indonesia 2014. Jakarta: Balitbangkes RI, 2014

9. Butte NF, Wong WW, Treuth MS, Ellis KJ, Smith EOBh. Energy requirements during pregnancy based on total energy expenditure and energy deposition. The American Journal of Clinical Nutrition 2004;79(6):1078-1087

10. Lembaga IImu Pengetahuan Indonesia. Widya Karya Pabngan dan Gizi ke X. Jakarta: LIPI, 2008

11. Hati-hati stress kerja ibu hamil berpengaruh pada berat bayi. Available from: http://babyorchestra.wordpress.com/tag/pe ngaruh-jenis-pekerjaan-ibu-hamil-terhadapjanin/. 
12. Yongky, Hardinsyah, Gulardi, Marhamah. Status gizi awal kehamilan dan pertambahan berat badan ibu hamil kaitannya dengan BBLR. Jurnal Gizi dan Pangan 2009;4 (1): 8-12. 